\title{
Karakteristik Hasil Ultrasonografi Payudara pada Program Deteksi Dini Kanker Payudara di Kota Solo
}

\author{
Rachmi Fauziah Rahayu ${ }^{1 *}$, Ropitasari ${ }^{2}$, Adam Prabata ${ }^{3}$ dan Luths Maharina ${ }^{4}$ \\ ${ }^{1}$ KSM Radiologi RSUD Dr Moewardi, Fakultas Kedokteran, Universitas Sebelas Maret, Surakarta, Indonesia; \\ ${ }^{2}$ Program Studi D3 Kebidanan SV Universitas Sebelas Maret, Surakarta, Indonesia; ${ }^{3}$ Cardiovascular Division, \\ Internal Medicine Department, Graduate Scool of Medicine, Kobe University, Japan; ${ }^{4}$ PPDS Radiologi Universitas \\ Sebelas Maret, RSUD Dr. Moewardi, Surakarta, Indonesia
}

Diterima: 11 April 2020; Disetujui: 21 April 2020

\begin{abstract}
Abstrak
Kanker payudara merupakan kanker yang paling banyak ditemui pada perempuan di seluruh dunia, termasuk di Indonesia. Kanker payudara menempati peringkat kedua kematian akibat kanker terbanyak di Indonesia dengan 22.000 kematian pada tahun 2018. Angka kematian yang tinggi tersebut diperparah dengan fakta bahwa $80 \%$ kasus kanker payudara di Indonesia terdeteksi saat sudah berada pada stadium lanjut, sehingga meningkatkan angka morbiditas dan mortalitas. Menanggapi permasalahan tersebut, kami menyelenggarakan kegiatan pengabdian masyarakat dalam bentuk penyuluhan metode SADARI (pemeriksaan payudara sendiri) dan pemeriksaan ultrasonografi payudara gratis. Kegiatan penyuluhan dilakukan dalam rangka meningkatkan pengetahuan dan kewaspadaan masyarakat terhadap kanker payudara, sedangkan pemeriksaan ultrasonografi secara gratis dilakukan untuk memberikan akses salah satu metode deteksi dini kanker payudara bagi masyarakat. Hasil deteksi dini melalui pemeriksaan ultrasonografi berhasil menemukan 9 orang (16,4\% peserta) yang memiliki lesi payudara serta 11 orang (20,0\% peserta) dengan keterlibatan kelenjar getah bening. Berdasarkan rata-rata usia peserta 47,4 tahun, program pengabdian masyarakat yang diselenggarakan termasuk tepat sasaran, sesuai dengan kelompok usia yang berisiko mengidap kanker payudara. Peningkatan pengetahuan dan kesadaran masyarakat terhadap pentingnya deteksi dini kanker payudara, sekaligus memperkaya data hasil pemeriksaan ultrasonografi payudara di Indonesia, khususnya Kota Solo, merupakan sasaran dan dampak yang diharapkan dari kegiatan pengabdian masyarakat ini.
\end{abstract}

Kata kunci: deteksi dini; kanker payudara; penyuluhan; ultrasonografi

\section{Characteristics of Breast Ultrasound Results in the Early Detection of Breast Cancer in Solo}

\begin{abstract}
Breast cancer is the most common cancer found in women worldwide, including Indonesia. Breast cancer was the most second cancer-related death in Indonesia with 22,000 mortality cases in 2018. The high mortality rate is worsened by the fact that $80 \%$ breast cancer cases in Indonesia was detected when its already in advanced stage, so the morbidity and mortality rate will be high. In response to those problems, we held a community service activity which comprises counselling of breast self-examination (BSE) methods and free breast ultrasonography examination. Counselling was held to improve knowledge and awareness regarding breast cancer, whereas free breast ultrasonography examination was held to give access of one of breast cancer early detection method for community. We found 9

\footnotetext{
* Corresponding author: rachmifr@yahoo.com
}

Cite this as: Rahayu, R. F., Ropitasari, Prabata, A., \& Maharina, L. (2020). Karakteristik Hasil Ultrasonografi Payudara pada Program Deteksi Dini Kanker Payudara di Kota Solo. AgriHealth: Journal of Agri-food, Nutrition and Public Health, 1(1), 1-6. doi: http://dx.doi.org/10.20961/agrihealth.v1i1.41124
\end{abstract}


people (16.4\% of all participants) who had breast lesion and 11 people (20.0\% of all participants) who had lymph node involvement. The mean of age of the community service participants was 47.4 years old, so our community service program is right on the target, matching with the riskiest age group of breast cancer. Improving knowledge and awareness regarding the importance of early detection for breast cancer, then contributing to add breast ultrasonography examination data in Indonesia, especially at Solo, were the aim for this community service program.

Keywords: breast cancer; counselling; early detection; ultrasonography

\section{PENDAHULUAN}

Kanker payudara adalah kanker yang berasal dari sel yang berlokasi di payudara, yang terdiri atas sel kelenjar penghasil air susu, sel saluran air susu, atau jaringan lainnya. Kanker ini mayoritas terjadi pada wanita, meskipun juga dapat terjadi pada pria di sebagian kecil kasus (Yuliana, 2018). Kanker payudara merupakan kanker yang paling banyak ditemui pada perempuan serta menjadi salah satu penyebab morbiditas dan mortalitas pada perempuan di seluruh dunia (Becker, 2015). Berdasarkan data Global Cancer Observatory (GLOBOCAN), pada tahun 2018, terdapat 2 juta kasus baru kanker payudara dengan kurang lebih 600.000 kematian di seluruh dunia. Terdapat kurang lebih 58.000 kasus baru kanker payudara di Indonesia pada tahun 2018, dengan perkiraan jumlah kasus dalam 5 tahun terakhir sejumlah 160.000 kasus, sehingga menempatkan kanker payudara sebagai kasus kanker nomor 1 di Indonesia (Bray et al., 2018). Angka kematian akibat kanker payudara di Indonesia mencapai sekitar 22.000 kasus pada tahun 2018, yang menempatkan kanker payudara pada peringkat kedua kematian akibat kanker, setelah kanker paru (Bray et al., 2018).

Lebih dari $80 \%$ kasus kanker payudara di Indonesia didiagnosis pada stadium lanjut sehingga angka morbiditas dan mortalitasnya menjadi lebih tinggi (Yuliana, 2018). Kondisi ini semakin parah dengan fakta bahwa pengetahuan masyarakat Indonesia mengenai kanker payudara dan melakukan deteksi dini dalam bentuk pemeriksaan Pemeriksaan payudara sendiri (SADARI) atau menggunakan modalitas radiologi, seperti mammografi atau ultrasonografi masih minim (Thaha et al., 2017). Deteksi dini terhadap kanker payudara dapat membantu untuk menemukan kanker payudara stadium awal sehingga dapat meningkatkan angka kesembuhan. Kanker payudara stadium awal memiliki angka kesembuhan yang lebih besar dibandingkan kanker payudara stadium akhir. Penyebaran sel- sel kanker yang belum terjadi atau masih sedikit pada stadium awal merupakan salah satu faktor yang membantu meningkatkan angka kesembuhan (Qomariah et al., 2017).

Deteksi dini merupakan upaya pencegahan sekunder kanker payudara. Deteksi dini bertujuan untuk menurunkan angka morbiditas dan mortalitas akibat kanker payudara. Mendapatkan orang atau kelompok orang yang terdeteksi untuk kemudian dikonfirmasi sebagai kanker payudara adalah salah satu cara yang ingin dicapai pada program deteksi dini kanker payudara. Selain itu, melalui deteksi dini, diharapkan angka kesembuhan akan meningkat dan angka kekambuhan akan berkurang. Metode deteksi dini kanker payudara dapat dilakukan dengan berbagai metode yang secara garis besar dibagi menjadi dua antara lain pemeriksaan payudara secara klinis atau menggunakan modalitas radiologi (Komite Penanggulangan Kanker Nasional, 2017).

Pemeriksaan ultrasonografi (USG) payudara adalah salah satu alternatif modalitas radiologi untuk melakukan deteksi dini kanker payudara (Brem et al., 2015). USG payudara memiliki akurasi yang lebih tinggi pada payudara yang memiliki densitas kelenjar tinggi serta memiliki keunggulan berupa bebas radiasi (Wang et al., 2019). Pada payudara dengan densitas tinggi, USG diketahui memiliki sensitivitas $88 \%$, lebih tinggi dibandingkan dengan mammografi, standar baku emas pemeriksaan kanker payudara yang hanya 56\% (Geisel et al., 2018). Payudara dengan densitas kelenjar tinggi sering ditemukan pada perempuan dibawah usia 50 tahun dan lebih sering ditemukan pada populasi Asia dibandingkan dengan Eropa atau Amerika, sehingga lebih mewakili karakteristik payudara masyarakat Indonesia (Ohuchi et al., 2009; Brem et al., 2015).

Kurangnya pengetahuan dan kesadaran masyarakat terhadap kanker payudara ditambah dengan minimnya data deteksi dini kanker payudara, terutama menggunakan USG di 
Indonesia, menambah berat permasalahan kanker payudara di Indonesia. Kegiatan pengabdian masyarakat dalam bentuk pemeriksaan ultrasonografi gratis, yang dirangkai dengan kegiatan penyuluhan mengenai pentingnya pemeriksaan SADARI, pada kegiatan Car Free Day (CFD) di Kota Solo dilakukan dengan tujuan untuk meningkatkan pengetahuan masyarakat, sekaligus berkontribusi terhadap data deteksi dini kanker payudara di Indonesia, khususnya di Solo.

\section{BAHAN DAN METODE}

Secara garis besar, kegiatan pengabdian masyarakat ini dilakukan dalam 2 jenis kegiatan, yaitu kegiatan penyuluhan tentang pemeriksaan SADARI, dengan tujuan perempuan lebih sadar terhadap kanker payudara dan mampu untuk memeriksa payudaranya sendiri, serta kegiatan pemeriksaan ultrasonografi payudara. Kegiatan pengabdian masyarakat ini diselenggarakan oleh Program Pendidikan Dokter Spesialis (PPDS) Radiologi Universitas Sebelas Maret (UNS) RSUD Dr. Moewardi bekerja sama dengan Spesialis Bedah Konsultan Onkologi UNS RSUD Dr. Moewardi.

Penyuluhan pemeriksaan SADARI dilakukan pada kegiatan CFD di Jalan Slamet Riyadi Kota Solo pada tanggal 21 Oktober 2018. Total pasien yang dilakukan pemeriksaan ultraonografi adalah 55 pasien yang dibagi dalam dua kegiatan berbeda. Kegiatan pemeriksaan ultrasonografi payudara dilakukan pada tanggal 24 Oktober 2018 sejumlah 23 pasien dan pada tanggal 19 Januari 2018 sejumlah 32 pasien. Kegiatan pemeriksaan ultrasonografi terutama ditujukan bagi Komunitas Lovepink Solo. Pemeriksaan ultrasonografi payudara dilakukan oleh anggota PPDS (Program Pendidikan Dokter Spesialis) Radiologi UNS Dr. Moewardi. Ultra-sonografi dilakukan menggunakan USG Portable Phillips CX-50 dan USG Portable Mind Ray DP 10 dengan Probe Linier 5$10 \mathrm{MHz}$.

\section{HASIL DAN PEMBAHASAN}

Peserta yang bersedia untuk melakukan deteksi dini menggunakan modalitas ultrasonografi pada kegiatan ini berjumlah 55 orang yang dibagi dalam 2 sesi pemeriksaan. Berdasarkan sosiodemografis, didapatkan karakteristik usia dan pekerjaan peserta, seperti yang terlampir pada Tabel 1. Rata-rata \pm standar deviasi usia peserta pada penelitian ini adalah $47,4 \pm 11,2$ tahun. Berdasarkan pekerjaan, terdapat 1 orang $(1,8 \%)$ dengan status mahasiswa, masing-masing 5 orang $(9,1 \%)$ dengan pekerjaan pedagang, petani dan karyawan, 10 orang $(18,2 \%)$ dengan pekerjaan asisten rumah tangga dan 29 orang $(52,7 \%)$ dengan pekerjaan ibu rumah tangga.

Tabel 1. Karakteristik sosio demografis

\begin{tabular}{lcc}
\hline & $\begin{array}{c}\text { Jumlah } \\
\text { (orang) }\end{array}$ & $\begin{array}{c}\text { Frekuensi } \\
(\%)\end{array}$ \\
\hline Usia (tahun) & \multicolumn{2}{c}{$47,4 \pm 11,2$} \\
Pekerjaan & \multicolumn{2}{c}{} \\
Pedagang & 5 & 9,1 \\
Petani & 5 & 9,1 \\
Karyawan & 5 & 9,1 \\
Asisten rumah tangga & 10 & 18,2 \\
Pelajar & 1 & 1,8 \\
Ibu rumah tangga & 29 & 52,7 \\
\hline
\end{tabular}

Berdasarkan hasil pemeriksaan ultrasonografi (Tabel 2), didapatkan 9 orang (16,4\%) dengan temuan lesi payudara, yang terdiri atas 5 orang $(9,1 \%)$ dengan lesi di payudara kanan dan 4 orang (7,3\%) dengan lesi di payudara kiri. Ditemukan 4 orang $(7,3 \%)$ dengan lesi hypoechoic dan 1 orang $(1,8 \%)$ dengan lesi kistik anechoic pada payudara kanan, sedangkan pada payudara kiri ditemukan 3 orang $(5,5 \%)$ dan 1 orang $(1,8 \%)$ dengan lesi kistik anechoic. Keterlibatan kelenjar getah bening didapatkan pada 11 orang $(20,0 \%)$ dengan suspicious limfadenopati sejumlah 2 orang $(3,6 \%)$ dan non-suspicious limfadenopati sejumlah 9 orang $(16,4 \%)$. Para peserta yang mendapatkan temuan lesi baik di payudara maupun kelenjar getah bening akan melakukan pemeriksaan serta tindakan lebih lanjut dari Spesialis Bedah Onkologi UNS - RSUD Dr. Moewardi.

Tabel 2. Karakteristik pemeriksaan ultrasonografi

\begin{tabular}{lcc}
\hline & $\begin{array}{c}\text { Jumlah } \\
\text { (orang) }\end{array}$ & $\begin{array}{c}\text { Frekuensi } \\
(\%)\end{array}$ \\
\hline $\begin{array}{l}\text { Lesi payudara } \\
\text { Payudara kanan }\end{array}$ & 9 & 16,4 \\
$\quad$ Lesi hipoechoic & 4 & 7,3 \\
$\quad$ Lesi kistik anechoic & 1 & 1,8 \\
$\begin{array}{l}\text { Payudara kiri } \\
\text { Lesi hipoechoic }\end{array}$ & 3 & 5,5 \\
$\quad \begin{array}{l}\text { Lesi kistik anechoic } \\
\text { Keterlibatan kelenjar getah bening }\end{array}$ & 1,8 \\
$\quad \begin{array}{l}\text { Suspicious } \\
\text { limfadenopati }\end{array}$ & 2 & 3,6 \\
$\quad \begin{array}{l}\text { Non-suspicious } \\
\text { limfadenopati }\end{array}$ & 9 & 16,4 \\
\hline
\end{tabular}


Usia rata-rata 47,4 tahun yang didapatkan pada penelitian ini sesuai dengan rentang rata-rata usia insidens kanker payudara di Asia. Insidens kanker payudara di Jepang dimulai pada rentang usia 4549 tahun, sedangkan insidens kanker payudara di Amerika Serikat dan Eropa dimulai pada rentang usia diatas 50 tahun. Meskipun risiko kanker payudara dimulai pada usia yang lebih muda, namun angka insidens tertinggi untuk kanker payudara ditemukan pada usia 65-75 tahun (Mousavi-Jarrahi et al., 2013; Mubarik et al., 2019). Populasi Asia juga diketahui memiliki tingkat risiko yang berbeda dibandingkan dengan populasi Eropa dan Amerika (Parsa et al., 2006; Evans et al., 2018). Oleh karena itu, deteksi dini kanker payudara pada populasi Asia disarankan untuk perempuan diatas usia 40 tahun (Tsuchida et al., 2015). World Health Organization (WHO) merekomendasikan deteksi dini kanker payudara terutama pada rentang usia 50-59 tahun, meskipun pemeriksaan pada rentang usia 40-49 tahun juga tetap disarankan (WHO, 2014).

Manfaat kegiatan penyuluhan terhadap kanker payudara dan pemeriksaan SADARI adalah untuk menumbuhkan kesadaran masyarakat, terutama perempuan, terhadap risiko kanker payudara dan mengajarkan masyarakat agar mampu melaksanakan pemeriksaan payudara secara berkala dan mandiri. Kegiatan penyuluhan masyarakat tentang kanker payudara dan pemeriksaan SADARI dapat dilihat pada Gambar 1, Gambar 2 dan Gambar 3.

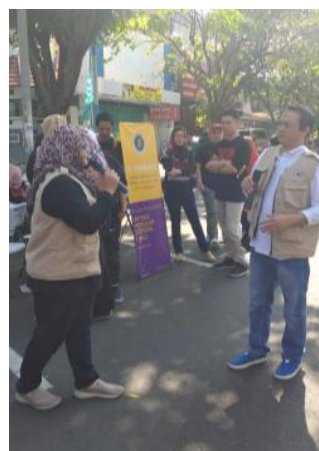

Gambar 1.

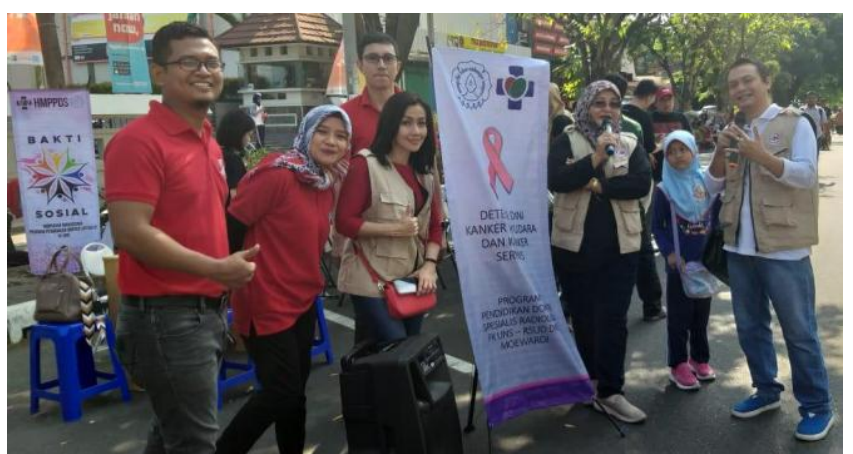

Gambar 2.

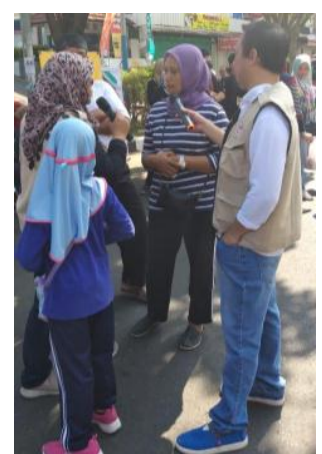

Gambar 3.

Keterangan: Gambar 1. Kegiatan tanya jawab pada penyuluhan kanker payudara dan SADARI di CFD Kota Solo; Gambar 2. Panitia kegiatan penyuluhan kanker payudara dan SADARI di CFD Kota Solo; Gambar 3. Suasana Kegiatan Penyuluhan Kanker Payudara dan SADARI di CFD Kota Solo

Tingkat pengetahuan masyarakat Indonesia, terutama perempuan, terhadap risiko kanker payudara dan pemeriksaan SADARI diketahui masih belum baik secara umum. Penelitian Thaha et al. (2017) menyatakan bahwa hanya terdapat $53 \%$ responden dengan tingkat pengetahuan tinggi pada wanita usia 20-45 tahun mengenai kanker payudara. Perilaku SADARI yang cukup baik juga hanya didapatkan pada 59\% responden. Penelitian Singam dan Wirakusuma (2017) menyatakan bahwa $89,7 \%$ remaja memiliki pengetahuan mengenai SADARI yang kurang baik serta praktik SADARI yang kurang adekuat. Penelitian Putri et al. (2011) menyatakan bahwa terdapat $53 \%$ remaja perempuan yang berpengetahuan kurang mengenai kanker payudara dan pemeriksaan SADARI. Penelitian-penelitian tersebut menunjukkan minimnya pengetahuan masyarakat, terutama perempuan, terhadap kanker payudara dan pemeriksaan SADARI, sehingga mayoritas kanker payudara terdeteksi di
Indonesia pada stadium lanjut. Oleh karena itu, kegiatan pengabdian masyarakat dalam bentuk edukasi terhadap kanker payudara dan pemeriksaan SADARI sangat penting untuk memperbaiki tingkat pengetahuan dan kesadaran masyarakat yang masih kurang.

Deteksi dini terhadap kanker payudara yang dilakukan dalam kegiatan pengabdian masyarakat merupakan kegiatan yang sangat bermanfaat untuk menurunkan angka kematian bagi pasien kanker payudara. Penelitian Nothacker et al. (2009) menyatakan bahwa deteksi dini kanker payudara diketahui paling bermanfaat pada kelompok usia 50-69 tahun. Terdapat penurunan risiko kematian akibat kanker payudara sebesar 23\% hingga $40 \%$ bagi perempuan berusia 50-69 tahun yang menjalani pemeriksaan deteksi dini untuk kanker payudara. Manfaat bagi perempuan berusia 40-49 tahun masih belum terlalu banyak, sehingga belum dapat disimpulkan, namun hasilnya condong mengarah kepada keberman- 
faatan (Lauby-Secretan et al., 2015; Seely et al., 2018). Beberapa panduan atau guideline dari berbagai negara menyatakan bahwa deteksi dini mulai dilakukan pada usia 40 tahun, namun masih ada beberapa negara yang menyarankan dimulai sejak usia 50 tahun (Seely et al., 2018). Meskipun kegiatan deteksi dini terhadap kanker payudara sangat bermanfaat, namun kegiatan tersebut dapat lebih tepat sasaran apabila sejak awal partisipannya disesuaikan dengan kelompok umur yang berisiko mengidap kanker payudara.

\section{KESIMPULAN}

Kegiatan pengabdian masyarakat diselenggarakan dalam bentuk penyuluhan dan pemeriksaan ultrasonografi gratis. Kegiatan penyuluhan dilakukan di acara CFD Kota Solo dengan tujuan meningkatkan pengetahuan masyarakat, terutama perempuan, mengenai kanker payudara dan cara pemeriksaannya, baik melalui pemeriksaan SADARI maupun menggunakan modalitas radiologi. Pada pemeriksaan ultrasonografi ditemukan $16,4 \%$ peserta dengan lesi payudara dan $20,0 \%$ peserta dengan keterlibatan kelenjar getah bening. Penyesuaian kelompok umur partisipan dengan kelompok umur yang paling berisiko mengidap kanker payudara disarankan untuk dilakukan pada kegiatan pengabdian masyarakat berikutnya agar kegiatan dapat berjalan dengan lebih tepat sasaran.

\section{DAFTAR PUSTAKA}

Becker, S. (2015). A Historic and Scientific Review of Breast Cancer: The Next Global Healthcare Challenge. International Journal of Gynecology and Obstetrics, 131, S36-S39. http://dx.doi.org/10.1016/j.ijgo.2015.03.015

Bray, F., Ferlay, J., Soerjomataram, I., Siegel, R.L., Torre, L. A., \& Jemal, A. (2018). Global Cancer Statistics 2018: GLOBOCAN estimates of incidence and mortality worldwide for 36 cancers in 185 countries. $C A$ : A Cancer Journal for Clinicians, 68(6), 394424. https://doi.org/10.3322/caac.21492

Brem, R. F., Lenihan, M. J., Lieberman, J., \& Torrente, J. (2015). Screening Breast Ultrasound: Past, Present, and Future. American Journal of Roentgenology, 204(2), 234-240. https://doi.org/10.2214/AJR.13.1207 2
Evans, D. G., Brentnall, A. R., Harvie, M., Astley, S., Harkness, E. F., Stavrinos, P., et al. (2018). Breast Cancer Risk in a Screening Cohort of Asian and White British/Irish Women from Manchester UK. BMC Public Health, 18(1), 178. https://doi.org/10.1186/s12889-018-5090 $-9$

Geisel, J., Raghu, M., \& Hooley, R. (2018). The Role of Ultrasound in Breast Cancer Screening: The Case for and Against Ultrasound. Seminars in Ultrasound, $C T$, and MRI, 39(1), 25-34. https://doi.org/10.1053/j.s ult.2017.09.006

Komite Penanggulangan Kanker Nasional. (2017). Panduan Penatalaksanaan Kanker Payudara. Komite Penanggulangan Kanker Nasional. Kementerian Kesehatan Republik Indonesia. Tersedia dari http://kanker.kemkes. go.id/guidelines/PPKPayudara.pdf

Lauby-Secretan, B., Scoccianti, C., Loomis, D., \& Benbrahim-Tallaa, L. (2015). Breast-Cancer Screening - Viewpoint of the IARC Working Group. The New England Journal of Medicine, 372(24), 2353-2358. https://doi.org/10.1056/N EJMsr1504363

Mousavi-Jarrahi, S. H., Kasaeian, A., Mansori, K., Ranjbaran, M., Khodadost, M., \& MosaviJarrahi, A. (2013). Addressing the Younger Age at Onset in Breast Cancer Patients in Asia: An Age-Period-Cohort Analysis of Fifty Years of Quality Data from the International Agency for Research on Cancer. Hindawi Publishing Corporation ISRN Oncology, 2013, 429862. http://dx.doi.org/10.1155/2013/429862

Mubarik, S., Malik, S. S., Wang, Z., Li, C., Fawad, M., \& Yu, C. (2019). Recent Insights into Breast Cancer Incidence Trends among Four Asian Countries using Age-PeriodCohort Model. Cancer Manag Res, 11, 81458155. https://doi.org/10.2147/CMAR.S20832 3

Nothacker, M., Duda, V., Hahn, M., Warm, M., Degenhardt, F., Madjar, H., et al. (2009). Early Detection of Breast Cancer: Benefits and Risks of Supplemental Breast Ultrasound in Asymptomatic Women with Mammo graphically Dense Breast Tissue. A Systematic Review. BMC Cancer, 20(9), 335. https:// doi.org/10.1186/1471-2407-9-335 
Ohuchi, N., Suzuki, A., Sakurai, Y., Kawai, M., Narikawa, Y., Narimatsu, H., \& Ishida, T. (2009). Current Status and Problems of Breast Cancer Screening. JMAJ, 52(1), 45-49. Tersedia dari https://www.med.or.jp/english/ journal/pdf/2009_01/045_049.pdf

Parsa, P., Kandiah, M., Abdul, R. H., \& Zulkefli, N. M. (2006). Barriers for Breast Cancer Screening among Asian Women: A Mini Literature Review. Asian Pacific Journal of Cancer Prevention, 7(4), 509-514. Tersedia dari https://www.ncbi.nlm.nih.gov/pubmed/17 250418

Putri, A, E. (2011). Hubungan Tingkat Pengetahuan dan Sikap remaja Putri Tentang SADARI Terhadap Perilaku SADARI di MA KMI Diniyyah Puteri Padang Panjang Bulan Februari 2011. Jakarta: Universitas Islam Negeri Syarif Hidayatullah. Tersedia dari http://repository.uinjkt.ac.id/dspace/bitstream/ 123456789/30632/1/DEFIRNA\%20INDAH\% 20PUTRI-FKIK.PDF

Qomariah, S., Sartika, W., \& Juwita, S. (2017). Deteksi Dini Kanker Payudara di Kelurahan Limbungan Kecamatan Rumbai Pesisir. Jurnal Pengabdian Masyarakat Multidisiplin, 1(1), 57-64. Tersedia dari http://jurnal.univrab.ac. id/index.php/jpm/article/view/397

Seely, J, M., \& Alhassan, T. (2018). Screening for Breast cancer in 2018 - What Should We be Doing Today? Current Oncology, 25(S1), S115-S124. https://dx.doi.org/10.3747\%2Fco. 25.3770

Singam, K, K., \& Wirakusuma, I, B. (2017). Gambaran Tingkat Pengetahuan dan Perilaku Tentang Pemeriksaan Payudara Sendiri
(SADARI) pada remaja Putri di Wilayah Kerja UPT Puskesmas Blahbatuh II Gianyar Bali Indonesia. Intisari Sains Medis, 8(3), 184-188. http://dx.doi.org/10.15562/ism.v8i3.135

Thaha, R., Widajadnja I, N., \& Hutasoit, G, A. (2017). Hubungan Tingkat Pengetahuan Tentang Kanker Payudara dengan Perilaku Pemeriksaan Payudara Sendiri (SADARI) pada wanita Usia 20-45 Tahun di Desa Sidera Kecamatan Sigi Biromaru. Jurnal Kesehatan Tadulako, 3(2), 40-46. http://jurnal.untad.ac. id/jurnal/index.php/HealthyTadulako/article/v iew/8745

Tsuchida, J., Nagahashi, M., Rashid, O, M., Takabe, K., \& Wakai, T. (2015). At What Age Should Screening Mammography be Recommended for Asian Women? Cancer Medicine, 4(7), 1136-1144. https://doi.org/ $10.1002 /$ cam 4.468

Wang, Y., Chen, H., Li, N., Ren, J., Zhang, K., Dai, M., et al. (2019). Ultrasound for Breast Cancer Screening in High-Risk Women: Results from a Population Based Cancer Screening Program in China. Frontiers in Oncology, 9, 286. https://dx.doi.org/ 10.3389/ fonc. 2019.00286

World Health Organization (WHO). (2014). WHO Position Paper on Mammography Screening. Geneva: WHO, 27-31. Tersedia dari https://www.who.int/cancer/publications/ mammography_screening/en/

Yuliana. (2018). Risiko dan Deteksi Dini Kanker Payudara. Cermin Dunia Kedokteran, 45(2), 144-149. Tersedia dari http://www.cdkjournal. com/index.php/CDK/article/view/177 